\title{
Impacts of Temperature and Carbon dioxide on Rice yield in Bangladesh
}

\author{
J K Basak¹, R A M Titumir2, J K Biswas ${ }^{3}$ and M Mohinuzzaman ${ }^{1}$
}

\begin{abstract}
This simulation study aimed to predict the effects of potential change of temperature and carbon dioxide on winter rice (Boro rice) production in Bangladesh. We assessed the effects of temperature and carbon dioxide on yield of Boro rice using DSSAT model for six major rice growing AgroEcological Zones (AEZs). The sensitivity analysis included variation of maximum and minimum temperature at $2^{\circ} \mathrm{C}$ and $4{ }^{\circ} \mathrm{C}$ and different levels of $\mathrm{CO}_{2}$ concentrations $(50 \mathrm{ppm}, 100 \mathrm{ppm}$ and 200 ppm) above the value reported in 2005 of IPCC Fourth Assessment Report (379 ppm). The model predicted that the change of maximum temperature drastically reduced rice yield at all selected locations. The average value of yield reductions (average percentage change of rice yield for 6 locations) of Boro rice were $6 \%$ and $16 \%$ for increasing maximum temperature at $2^{\circ} \mathrm{C}$ and $4{ }^{\circ} \mathrm{C}$ respectively. Minimum temperature had also negative impacts on Boro rice yields that reduced yield by $4 \%$ for $2^{\circ} \mathrm{C}$ and $8 \%$ for $4^{\circ} \mathrm{C}$. However, a slight increase in rice yield due to increase in $\mathrm{CO}_{2}$ concentration could not overcome the negative effect of temperature. Such yield reductions under changing climatic conditions could significantly affect the rice production in Bangladesh in future.
\end{abstract}

Key words: Bangladesh, Boro rice, climate change, DSSAT model, rice yield

\section{INTRODUCTION}

The impacts of climate change on agriculture production are global concerns. Bangladesh, where lives and livelihoods depend mainly on agriculture, is one of the most vulnerable countries due to climate change. Agriculture in Bangladesh is always vulnerable due to unfavorable weather events and climate conditions. Despite technological advances, such as improved crop varieties and irrigation systems, weather and climate are important factors, which play a significant role to agricultural productivity (Ahmed and Ryosuke, 2010).

Increasing food production and attaining food security in Bangladesh requires sustainable growth of agricultural sector. Bangladesh has a large agrarian base with 76 percent of total population is living in the rural areas and 90 percent of the rural population directly related with agriculture (Bangladesh Economics Review, 2011). In agricultural sector 43.6 percent of the country's labor force is always vulnerable due to changing climate conditions and unfavorable weather events. The sector is already under pressure for increasing food demand, problems associated with agricultural land and water resource depletion. The issues of climate change make the pressure more acute for the sector.

Population growth rate of Bangladesh is 2 million per year (Basak, 2009). It faces a tremendous challenge for providing food security for increasing population. Therefore, it is imperative to increase rice production in order to meet the growing demand for food of its growing population. Although, there have been ups and downs in the domestic production of food grain

\footnotetext{
${ }^{1}$ Assistant Professor, Department of Environmental Science and Hazard Studies, Noakhali Science and Technology University, Noakhali-3814

${ }^{2}$ Associate Professor, Department of Development Studies, University of Dhaka, Bangladesh

${ }^{3}$ Director General, Bangladesh Rice Research Institute (BRRI), Gazipur, Bangladesh

Corresponding author's email: basak.jkb@gmail.com
} 
The diverse climatic phenomena like changing rainfall patterns and temperature; there has been a significant loss of food grain production in every year. Therefore, systematic integration of environmental and economic development is essential to overcome the challenges faced by the agricultural sectors from the climatic conditions. Simulation studies have been carried out to assess the impacts of climate change and variability on rice productivity in Bangladesh (Basak, 2009, Basak et al., 2010; Mahmood et al., 2003; Mahmood, 1998; Karim et al., 1996) and some of these studies have predicted lower rice yield under different climate change scenarios. Basak (2009) and Basak et al. (2010) predicted significant reduction in yield of some varieties of Boro rice due to climate change; yield reductions of over $20 \%$ and $50 \%$ have also been predicted for the years 2050 and 2070 respectively. This study presents an assessment of the effects of climate change mainly temperature and carbon dioxide on Boro rice yield under different climate scenarios.

\section{METHODS}

\section{Selection of Simulation Locations}

The simulation study involved six major rice growing areas (Rajshahi (AEZ-11), Mymensingh (AEZ-9), Satkhira (AEZ-13), Barisal (AEZ-18), Comilla (AEZ-19) and Sylhet (AEZ-20)) in different Agro-Ecological Zones (AEZs) in Bangladesh. The weather and soil data were also collected for those selected locations.

\section{Selection of Variety}

The model uses a detailed set of crop specific genetic coefficients, which allows it to respond to diverse weather and management conditions. Therefore, in order to get reliable results from model simulations, it is necessary to have the appropriate genetic coefficients for the selected cultivar (Basak, 2009). The Boro rice variety BR3 has been selected in the present study because genetic coefficients for this variety are available in the DSSAT modeling system. Although this variety is not widely used at present, the effects of climate change and variability on this variety provides insights into possible impact of climate change on Boro rice yield in the future. In order to assess the effect of climate change on the rice varieties currently being grown in Bangladesh, it is necessary to determine their genetic coefficients through carefully controlled field and laboratory experiments for 1 to 2 years. Table 1 presents the genetic coefficients of BR3 Boro rice variety.

Table 1. Genetic coefficients for rice cultivar, grown in Bangladesh

\begin{tabular}{lllllllllll}
\hline \multirow{2}{*}{ Rice } & \multirow{2}{*}{ Cultivar } & \multicolumn{10}{c}{ Coefficients } & \multirow{2}{*}{ Source } \\
\cline { 3 - 10 } & & P1 & P2R & P5 & P2O & G1 & G2 & G3 & G4 & \\
\hline Boro & BR3 & 650.0 & 90.0 & 400.0 & 13.0 & 65.0 & 0.025 & 1.0 & 1.0 & DSSAT v4 \\
\hline
\end{tabular}

Crop Management Data

Crop management data required by the model include planting method, transplanting date, row spacing, seedling per hill, fertilizer application dose and irrigation. Table 2 shows the major crop management input data used in the model for all simulations in the present study.

\section{Crop Model (DSSAT)}

The DSSAT modeling system (Ritche et al. 1987; Hoogenboom et al. 2003) is an advanced physiologically based rice crop growth simulation model and has been widely applied to understand the relationship between rice and its environment. The model estimates yield of 
irrigated, non-irrigated rice and other crops like wheat, potato etc, determine duration of growth stages, dry matter production and portioning, root system dynamics, effect of soil water and soil nitrogen contents on photosynthesis, carbon balance and water balance. Ritchie et al. (1987) and Hoogenboom et al. (2003) have provided a detailed description of the model.

Table 2. Crop management data used in the model simulations

\begin{tabular}{ll}
\hline Parameter & Input data \\
\hline Planting method & Transplant \\
Transplanting date & 15 January \\
Plant population at seedling & 35 plants per $\mathrm{m}^{2}$ \\
Plant population at emergence & 33 plants per $\mathrm{m}^{2}$ \\
Row spacing & $20 \mathrm{~cm}$ \\
Planting depth & $3 \mathrm{~cm}$ \\
Transplant age & 35 days \\
Plant per Hill & 2 \\
Fertilizer (N) application & \\
$\bullet \quad 18$ days after transplanting & $30 \mathrm{~kg} \mathrm{ha}^{-1}$ \\
$\bullet \quad 38$ days after transplanting & $70 \mathrm{~kg} \mathrm{ha}^{-1}$ \\
$\bullet \quad 56$ days after transplanting & $25 \mathrm{~kg} \mathrm{ha}^{-1}$ \\
Application of irrigation & $860 \mathrm{~mm} \mathrm{in} 14$ applications
\end{tabular}

\section{Soil Data}

Soil profile data used in the model were taken from AEZ-19 covering Kishoregani, Habigang, Bramanbaria, Comilla, Chandpur, Feni, Noakhali, Laksmipur, Narsingdi, Narayanganj, Dhaka, Shariatpur, Modaripur, Gopalganj and Barisal districts (Table 3).

Table 3. Soil profile data for Old Meghna Estuarine Floodplain (AEZ-19)

\begin{tabular}{llllllll}
\hline $\begin{array}{l}\text { Depth } \\
\text { bottom } \\
\mathrm{cm}\end{array}$ & $\begin{array}{l}\text { Clay } \\
\%\end{array}$ & $\begin{array}{l}\text { Silt } \\
\%\end{array}$ & $\begin{array}{l}\text { Stones } \\
\%\end{array}$ & $\begin{array}{l}\text { Organic } \\
\text { carbon } \\
\%\end{array}$ & $\begin{array}{l}\mathrm{pH} \text { in } \\
\text { water }\end{array}$ & $\begin{array}{l}\text { Cation exchange } \\
\text { capacity } \\
\text { meq/100gm }\end{array}$ & $\begin{array}{l}\text { Total } \\
\text { nitrogen } \\
\%\end{array}$ \\
\hline 5 & 13 & 38 & 0 & 1.51 & 5.6 & 11.3 & 0.14 \\
15 & 13 & 38 & 0 & 1.51 & 5.6 & 11.3 & 0.14 \\
30 & 13 & 38 & 0 & 1.43 & 5.6 & 11.3 & 0.13 \\
45 & 13 & 38 & 0 & 1.22 & 5.6 & 11.3 & 0.11
\end{tabular}

Source: BRRI (2006)

\section{Weather Data}

Weather data including daily average maximum and minimum temperature, daily rainfall, carbon dioxide were collected from Bangladesh Meteorological Department (BMD). The Intergovernmental Panel on Climate Change (IPCC) considers four families of socioeconomic development and associated emission scenarios, known as Special Report on Emissions Scenarios (SRES) A2, B2, A1, and B1. Depending on the SRES emission scenario and climate models considered, global mean surface temperature was projected to rise in a range from $1.8^{\circ} \mathrm{C}$ (with a range from $1.1^{\circ} \mathrm{C}$ to $2.9^{\circ} \mathrm{C}$ for SRES B1) to $4.0^{\circ} \mathrm{C}$ (with a range from $2.4^{\circ} \mathrm{C}$ to $6.4^{\circ} \mathrm{C}$ for A1) by 2100 . On the basis of the Fourth Assessment report of IPCC (2005), the assumptions of maximum and minimum temperatures were considered $2^{\circ} \mathrm{C}$ and $4^{\circ} \mathrm{C}$. 
Another important climate change is the increase in atmospheric carbon dioxide $\left(\mathrm{CO}_{2}\right)$ concentrations. Depending on the SRES emission scenario, the atmospheric $\mathrm{CO}_{2}$ concentration was projected to increase from $\approx 379 \mathrm{ppm}$ to $>550 \mathrm{ppm}$ by 2100 in SRES B1 to $>800$ ppm in SRES A1FI. In this study, carbon dioxide at a level of 50 ppm, 100 ppm and 200 ppm with 379 ppm was considered to see their combined effect on rice yield.

\section{MODEL APPLICATIONS AND RESULTS}

\section{Model Simulations}

Table 4 shows the predicted yields of Boro rice variety for six major rice growing locations in Bangladesh. These predictions have been made using a fixed concentration of atmospheric $\mathrm{CO}_{2}$ of $379 \mathrm{ppm}$ (the value reported for the year 2005 in the fourth assessment report of IPCC), irrigation application (860 $\mathrm{mm}$ in 14 applications), fertilizer dose (125 kg/ha in 3 applications of nitrogen) and for planting date of 15 January. Soil data and climate data were varied on location basis.

From the model simulation, maximum rice yield was found $5427 \mathrm{~kg} / \mathrm{ha}$ at Comilla and minimum $3102 \mathrm{~kg} / \mathrm{ha}$ at Rajshahi in 2008. Moreover, yield of rice was above $5000 \mathrm{~kg} / \mathrm{ha}$ for the locations of Barisal, Comilla and Sylhet, whereas, it was below $4000 \mathrm{~kg} / \mathrm{ha}$ for Rajshahi and Satkhira. Therefore, significant amount of yield of Boro rice varied in different locations for different climatic and hydrological properties of soil. Comparing the simulation results location-wise, it was found that Rajshahi was the most vulnerable rice growing region among the six AEZs in Bangladesh. The average yield of Boro rice for these six locations was $4564 \mathrm{~kg} / \mathrm{ha}$ in 2008.

Table 4. Location-wise prediction of rice yield in 2008

\begin{tabular}{lllllll}
\hline Location & Rajshah & Mymensingh & Satkhira & Barisal & Comi & Sylhe \\
\hline Rice yield $\left(\mathrm{kg} \mathrm{ha}^{-1}\right)$ & 3102 & 4468 & 3934 & 5096 & 5427 & 5359 \\
\hline
\end{tabular}

Effects of Maximum Temperature (Tmax) on Boro Rice Production

Maximum temperature had significant negative impacts on Boro rice yield that reduced about 2.6 to $13.5 \%$ due to increase $2^{\circ} \mathrm{C}$ maximum temperature and 0.11 to $28.7 \%$ for $4^{\circ} \mathrm{C}$. Table 5 shows that the maximum temperature had the most significant negative impact at Satkhira and less at Sylhet. From the analysis of daily average maximum temperature, monthly average maximum temperature at Satkhira in January, February, March, April and May (growing season of Boro rice) were $25.3^{\circ} \mathrm{C}, 26.7^{\circ} \mathrm{C}, 32.5^{\circ} \mathrm{C}, 34.9^{\circ} \mathrm{C}$ and $36.1^{\circ} \mathrm{C}$, respectively in 2008 . Increased maximum temperature $2^{\circ} \mathrm{C}$ above the average value, yield reduction was above $13 \%$ and above $28 \%$ for $4^{\circ} \mathrm{C}$ at Satkhira. Similar results were also found for other regions in Bangladesh but percentages of change in rice yields were different. The average value (average percentage change in rice yield for six locations) of yield reduction for maximum temperature was above $6 \%$ for $2^{\circ} \mathrm{C}$ and $16 \%$ for $4^{\circ} \mathrm{C}$ (Fig. 1). 


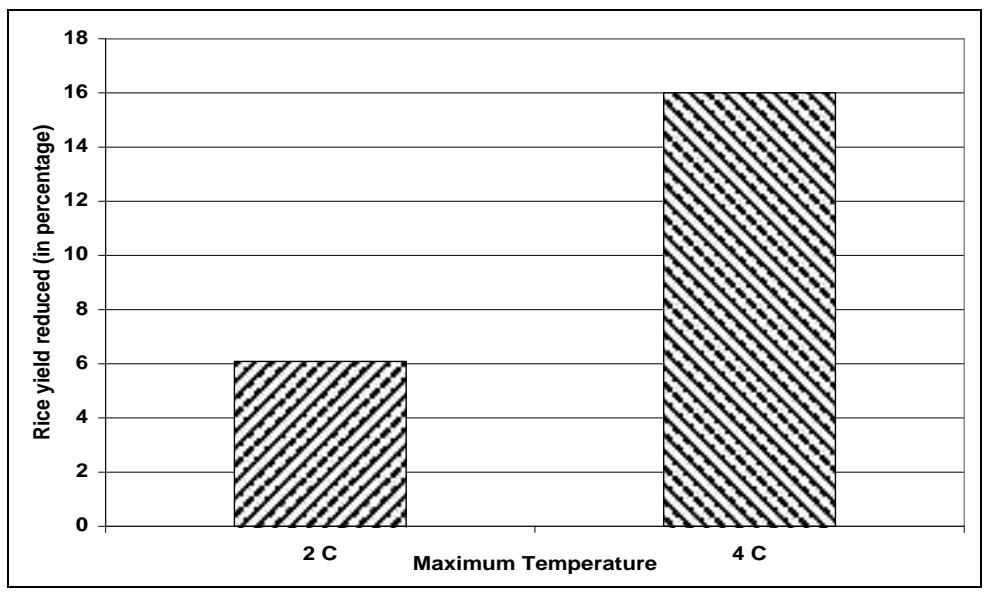

Fig. 1. Percentage of average reduction of rice yield for maximum temperature

Table 5. Percentage of change in Boro rice yield under various scenarios of maximum Temperature

\begin{tabular}{|c|c|c|c|}
\hline Location & Climate change phenomena & $\begin{array}{l}\text { Rice yield } \\
\left(\mathrm{Kg} \mathrm{ha}^{-1}\right)\end{array}$ & $\begin{array}{l}\% \text { change of } \\
\text { rice yield }\end{array}$ \\
\hline \multirow{2}{*}{ Rajshahi } & Increased Maximum Temperature $2^{\circ} \mathrm{C}$ & 3020 & -02.60 \\
\hline & Increased Maximum Temperature $4^{0} \mathrm{C}$ & 2707 & -12.70 \\
\hline \multirow{2}{*}{ Mymensingh } & Increased Maximum Temperature $2^{\circ} \mathrm{C}$ & 4167 & -06.74 \\
\hline & Increased Maximum Temperature $4^{0} \mathrm{C}$ & 4001 & -10.45 \\
\hline \multirow{2}{*}{ Satkhira } & Increased Maximum Temperature $2^{\circ} \mathrm{C}$ & 3402 & -13.50 \\
\hline & Increased Maximum Temperature $4^{0} \mathrm{C}$ & 2860 & -28.70 \\
\hline \multirow{2}{*}{ Barisal } & Increased Maximum Temperature $2^{0} \mathrm{C}$ & 4761 & -06.60 \\
\hline & Increased Maximum Temperature $4^{0} \mathrm{C}$ & 3954 & -22.40 \\
\hline \multirow{2}{*}{ Comilla } & Increased Maximum Temperature $2^{\circ} \mathrm{C}$ & 4831 & -11.00 \\
\hline & Increased Maximum Temperature $4^{0} \mathrm{C}$ & 4271 & -21.30 \\
\hline \multirow{2}{*}{ Sylhet } & Increased Maximum Temperature $2^{0} \mathrm{C}$ & 5569 & +03.90 \\
\hline & Increased Maximum Temperature $4^{0} \mathrm{C}$ & 5353 & -00.11 \\
\hline
\end{tabular}

\section{Effects of Minimum Temperature (Tmin) on Boro Rice Production}

As like as maximum temperature, minimum temperature had also negative impact on Boro rice yield that reduced about 0.40 to $13.1 \%$ due to increase of $2^{\circ} \mathrm{C}$ minimum temperature and 0.11 to $15.5 \%$ for $4^{0} \mathrm{C}$. Table 6 shows that the negative impact of minimum temperature at Satkhira, which was more vulnerable, compared to other five regions in Bangladesh. Calculated monthly average minimum temperature from daily average values were $12.5^{\circ} \mathrm{C}$, $14.5^{\circ} \mathrm{C}, 22.0^{\circ} \mathrm{C}, 24.1^{\circ} \mathrm{C}$ and $24.9^{\circ} \mathrm{C}$ in January, February, March, April and May respectively in 2008 at Satkhira. Increased minimum temperature at $2^{\circ} \mathrm{C}$ and $4^{\circ} \mathrm{C}$ above those monthly average values, yield reduced about $13 \%$ and $14 \%$, respectively at Satkhira. Similar results were also found for other regions in Bangladesh but the percentages of change in rice yields were different. The average figures (average percentage of change in rice yield for six locations) of yield reduction for minimum temperature were above $4 \%$ for $2^{\circ} \mathrm{C}$ and above $8.5 \%$ for $4^{\circ} \mathrm{C}$ (Fig. 2). Therefore, maximum temperature had the most significant negative effect on rice yield compared to the minimum temperature. 


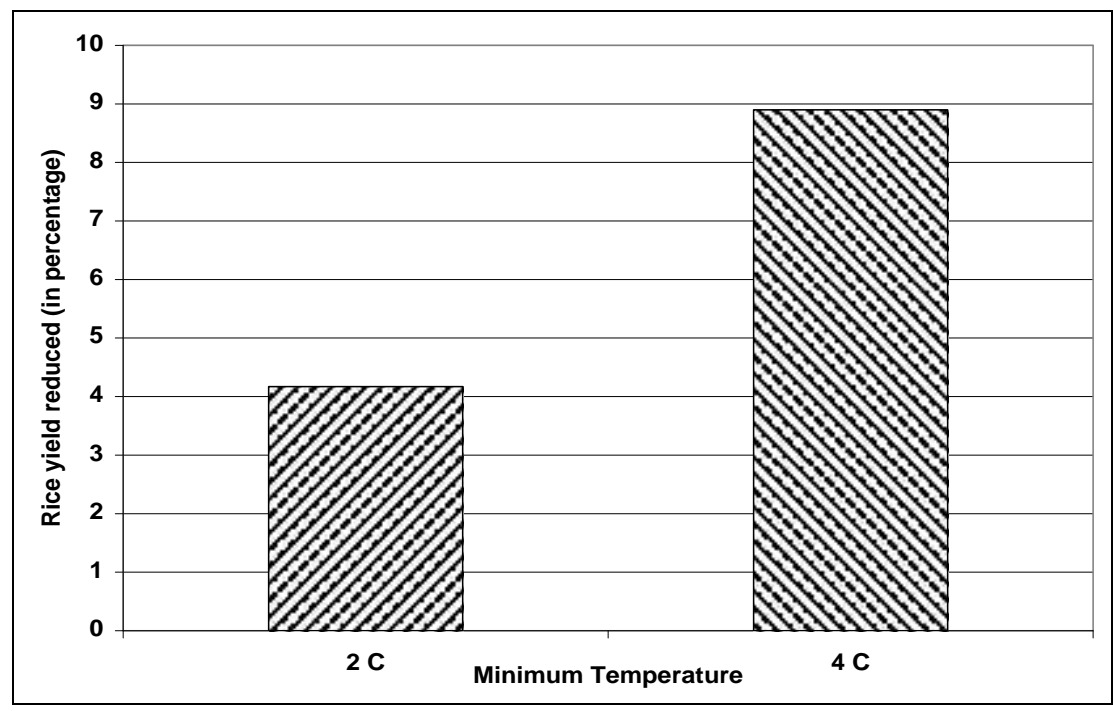

Fig. 2. Percentage of average reduction of rice yield for minimum temperature

Table 6. Percentage of change of Boro rice yield under various scenarios of minimum temperature

\begin{tabular}{llll}
\hline \multirow{2}{*}{ Location } & Increased Minimum Temperature & $\begin{array}{l}\text { Rice yield } \\
\left(\mathrm{Kg} \mathrm{ha}^{-1}\right)\end{array}$ & $\begin{array}{l}\% \text { change of } \\
\text { rice yield }\end{array}$ \\
\hline \multirow{2}{*}{ Rajshahi } & $2^{0} \mathrm{C}$ & 3051 & -01.67 \\
\cline { 2 - 4 } & $4^{0} \mathrm{C}$ & 2927 & -05.60 \\
\hline \multirow{2}{*}{ Mymensingh } & $2^{0} \mathrm{C}$ & 4450 & -00.40 \\
\cline { 2 - 4 } & $4^{0} \mathrm{C}$ & 4323 & -03.24 \\
\hline \multirow{2}{*}{ Satkhira } & $2^{0} \mathrm{C}$ & 3418 & -13.10 \\
\hline \multirow{2}{*}{ Barisal } & $4^{0} \mathrm{C}$ & 3384 & -14.00 \\
\hline \multirow{2}{*}{ Comilla } & $2^{0} \mathrm{C}$ & 4917 & -03.50 \\
\hline \multirow{2}{*}{ Sylhet } & $4^{0} \mathrm{C}$ & 4334 & -14.90 \\
\hline
\end{tabular}

\section{Combined Effects of Maximum and Minimum Temperature on Boro Rice Production}

Combined effects of maximum and minimum temperatures were more significant compared to their individual effect on rice production. Rice yield drastically reduced due to ${ }^{\circ} \mathrm{C}$ and $4^{\circ} \mathrm{C}$ increase in maximum and minimum temperature. Boro rice yield reduced 3.2 to $18.7 \%$ for $2^{\circ} \mathrm{C}$ and for $4^{\circ} \mathrm{C}$ increase that was about 5.33 to $36.0 \%$. The most affected area was Comilla where yield reduced $18.7 \%$ and $36.0 \%$ for their combined effect of $2^{\circ} \mathrm{C}$ and $4{ }^{\circ} \mathrm{C}$, respectively (Table 7 ). The average figures (average percentage change in rice yield for six locations) of yield reduction of the two temperature parameters were above $10.4 \%$ for $2^{\circ} \mathrm{C}$ and above $22.87 \%$ for $4^{\circ} \mathrm{C}$ (Fig. 3). 


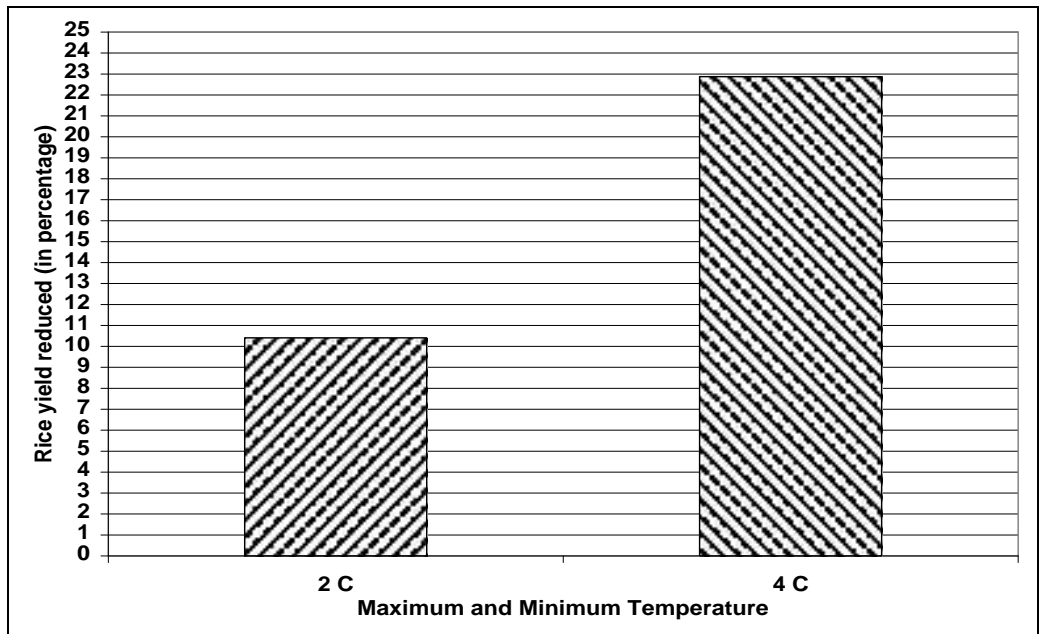

Fig. 3. Percentage of yield reduction for maximum and minimum temperature

Table 7. Percentage change of Boro rice yield under various scenarios of maximum and minimum temperature

\begin{tabular}{|c|c|c|c|}
\hline Location & Climate change phenomena & Rice yield (Kg ha-1) & $\%$ change of rice yield \\
\hline \multirow{2}{*}{ Rajshahi } & Increased $\operatorname{Tmax} 2^{\circ} \mathrm{C}+\operatorname{Tmin} 2^{\circ} \mathrm{C}$ & 2816 & -09.20 \\
\hline & Increased $\operatorname{Tmax} 4^{0} \mathrm{C}+\operatorname{Tmin} 4^{0} \mathrm{C}$ & 2481 & -20.00 \\
\hline \multirow{2}{*}{ Mymensingh } & Increased $\operatorname{Tmax} 2^{\circ} \mathrm{C}+\operatorname{Tmin} 2^{\circ} \mathrm{C}$ & 4323 & -03.24 \\
\hline & Increased $\operatorname{Tmax} 4^{0} \mathrm{C}+\operatorname{Tmin} 4^{0} \mathrm{C}$ & 3230 & -05.33 \\
\hline \multirow{2}{*}{ Satkhira } & Increased $\operatorname{Tmax} 2^{\circ} \mathrm{C}+\operatorname{Tmin} 2^{\circ} \mathrm{C}$ & 3225 & -18.00 \\
\hline & Increased $\operatorname{Tmax} 4^{0} \mathrm{C}+\operatorname{Tmin} 4^{0} \mathrm{C}$ & 2945 & -25.10 \\
\hline \multirow{2}{*}{ Barisal } & Increased $\operatorname{Tmax} 2^{\circ} \mathrm{C}+\operatorname{Tmin} 2^{\circ} \mathrm{C}$ & 4267 & -16.30 \\
\hline & Increased $\operatorname{Tmax} 4^{0} \mathrm{C}+\operatorname{Tmin} 4^{\circ} \mathrm{C}$ & 3446 & -32.30 \\
\hline \multirow{2}{*}{ Comilla } & Increased $\operatorname{Tmax} 2^{\circ} \mathrm{C}+\operatorname{Tmin} 2^{\circ} \mathrm{C}$ & 4413 & -18.70 \\
\hline & Increased $\operatorname{Tmax} 4^{0} \mathrm{C}+\operatorname{Tmin} 4^{0} \mathrm{C}$ & 3471 & -36.00 \\
\hline \multirow{2}{*}{ Sylhet } & Increased $\operatorname{Tmax} 2^{\circ} \mathrm{C}+\operatorname{Tmin} 2^{\circ} \mathrm{C}$ & 5518 & +03.00 \\
\hline & Increased $\operatorname{Tmax} 4^{0} \mathrm{C}+\operatorname{Tmin} 4^{0} \mathrm{C}$ & 4369 & -18.50 \\
\hline
\end{tabular}

\section{Effects of Carbon Dioxide on Boro Rice Production}

Table 8 shows the predicting rice yield under different concentrations $\mathrm{CO}_{2}$. These predictions have been made using a fixed concentration of atmospheric $\mathrm{CO}_{2}$ of $379 \mathrm{ppm}$ (the value reported for the year 2005 in the fourth assessment report of IPCC) and then increased at a level of $50 \mathrm{ppm}, 100 \mathrm{ppm}$ and $200 \mathrm{ppm}$. Increased atmospheric $\mathrm{CO}_{2}$ concentration was likely to have some positive effect on rice yield. If the level of atmospheric $\mathrm{CO}_{2}$ concentration increased $50 \mathrm{ppm}$ from the year 2005 (IPCC reported value $379 \mathrm{ppm}$ ), Boro rice yields increased about 2.1 to $4.4 \%$ and 4.0 to $9.6 \%$ for $100 \mathrm{ppm}$ and 5.2 to $18.2 \%$ for 200 ppm. The maximum positive effect of $\mathrm{CO}_{2}$ was found at Comilla for $200 \mathrm{ppm}$ (increased $18 \%$ ) and minimum at Sylhet (only 5.2\%). 


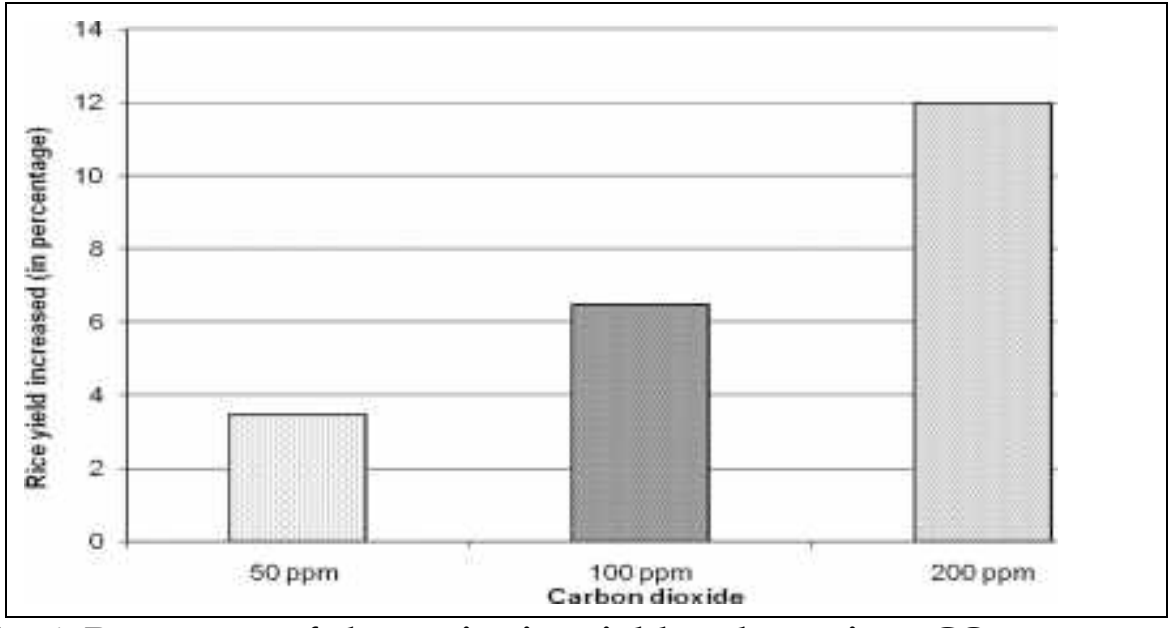

Fig. 4. Percentage of change in rice yield under various $\mathrm{CO}_{2}$ concentrations

Table 8. Percentage of change in rice yield under various $\mathrm{CO}_{2}$ concentrations

\begin{tabular}{|c|c|c|c|}
\hline Location & Climate change phenomena & Rice yield $\left(\mathrm{kg} \mathrm{ha}^{-1}\right)$ & $\%$ change in rice yield \\
\hline \multirow{3}{*}{ Rajshahi } & $+50 \mathrm{ppm} \mathrm{CO}_{2}$ & 3234 & +04.30 \\
\hline & $+100 \mathrm{ppm} \mathrm{CO}_{2}$ & 3346 & +07.90 \\
\hline & +200 ppm $\mathrm{CO}_{2}$ & 3638 & +17.30 \\
\hline \multirow{3}{*}{ Mymensingh } & $+50 \mathrm{ppm} \mathrm{CO}_{2}$ & 4612 & +03.22 \\
\hline & +100 ppm $\mathrm{CO}_{2}$ & 4686 & +04.88 \\
\hline & $+200 \mathrm{ppm} \mathrm{CO}_{2}$ & 4858 & +08.72 \\
\hline \multirow{3}{*}{ Satkhira } & $+50 \mathrm{ppm} \mathrm{CO} 2$ & 4055 & +03.10 \\
\hline & $+100 \mathrm{ppm} \mathrm{CO}_{2}$ & 4107 & +04.40 \\
\hline & +200 ppm $\mathrm{CO}_{2}$ & 4367 & +11.00 \\
\hline \multirow{3}{*}{ Barisal } & $+50 \mathrm{ppm} \mathrm{CO}_{2}$ & 5320 & +04.40 \\
\hline & $+100 \mathrm{ppm} \mathrm{CO}_{2}$ & 5502 & +07.80 \\
\hline & +200 ppm $\mathrm{CO}_{2}$ & 5675 & +11.40 \\
\hline \multirow{3}{*}{ Comilla } & $+50 \mathrm{ppm} \mathrm{CO} 2$ & 5626 & +03.70 \\
\hline & $+100 \mathrm{ppm} \mathrm{CO}_{2}$ & 5947 & +09.60 \\
\hline & $+200 \mathrm{ppm} \mathrm{CO}_{2}$ & 6413 & +18.20 \\
\hline \multirow{3}{*}{ Sylhet } & $+50 \mathrm{ppm} \mathrm{CO}_{2}$ & 5470 & +02.10 \\
\hline & +100 ppm $\mathrm{CO}_{2}$ & 5574 & +04.00 \\
\hline & $+200 \mathrm{ppm} \mathrm{CO}_{2}$ & 5638 & +05.20 \\
\hline
\end{tabular}

Table 9. Percentage of change in rice yield under various climatic scenarios 


\begin{tabular}{|c|c|c|c|}
\hline Location & Climate change phenomena & Rice yield $\left(\mathrm{kg} \mathrm{ha}^{-1}\right)$ & $\%$ change of rice yield \\
\hline \multirow{6}{*}{ Rajshahi } & $\operatorname{Tmax} 2^{\circ} \mathrm{C}+\operatorname{Tmin} 2^{\circ} \mathrm{C}+50 \mathrm{ppm} \mathrm{CO}$ & 2907 & -06.30 \\
\hline & $\operatorname{Tmax} 2^{\circ} \mathrm{C}+\operatorname{Tmin} 2^{\circ} \mathrm{C}+100 \mathrm{ppm} \mathrm{CO}$ & 3030 & -02.30 \\
\hline & $\operatorname{Tmax} 2^{\circ} \mathrm{C}+\operatorname{Tmin} 2^{\circ} \mathrm{C}+200 \mathrm{ppm} \mathrm{CO}$ & 3237 & +04.40 \\
\hline & $\operatorname{Tmax} 4^{\circ} \mathrm{C}+\operatorname{Tmin} 4^{0} \mathrm{C}+50 \mathrm{ppm} \mathrm{CO} 2$ & 2616 & -15.70 \\
\hline & $\operatorname{Tmax} 4^{\circ} \mathrm{C}+\operatorname{Tmin} 4^{\circ} \mathrm{C}+100 \mathrm{ppm} \mathrm{CO} \mathrm{CO}_{2}$ & 2712 & -12.60 \\
\hline & $\operatorname{Tmax} 4^{\circ} \mathrm{C}+\operatorname{Tmin} 4^{0} \mathrm{C}+200 \mathrm{ppm} \mathrm{CO}$ & 3196 & +03.00 \\
\hline \multirow{6}{*}{ Mymensingh } & $\operatorname{Tmax} 2^{\circ} \mathrm{C}+\operatorname{Tmin} 2^{\circ} \mathrm{C}+50 \mathrm{ppm} \mathrm{CO}$ & 4245 & -05.00 \\
\hline & $\operatorname{Tmax} 2^{\circ} \mathrm{C}+\operatorname{Tmin} 2^{\circ} \mathrm{C}+100 \mathrm{ppm} \mathrm{CO}$ & 4369 & -02.21 \\
\hline & $\operatorname{Tmax} 2^{\circ} \mathrm{C}+\operatorname{Tmin} 2^{\circ} \mathrm{C}+200 \mathrm{ppm} \mathrm{CO}$ & 4604 & +03.04 \\
\hline & $\operatorname{Tmax} 4^{\circ} \mathrm{C}+\operatorname{Tmin} 4^{0} \mathrm{C}+50 \mathrm{ppm} \mathrm{CO} \mathrm{CO}_{2}$ & 3162 & -29.23 \\
\hline & $\operatorname{Tmax} 4^{\circ} \mathrm{C}+\operatorname{Tmin} 4^{0} \mathrm{C}+100 \mathrm{ppm} \mathrm{CO}$ & 3229 & -27.73 \\
\hline & $\operatorname{Tmax} 4^{\circ} \mathrm{C}+\operatorname{Tmin} 4^{0} \mathrm{C}+200 p p m \mathrm{CO}_{2}$ & 3401 & -23.88 \\
\hline \multirow{6}{*}{ Satkhira } & $\operatorname{Tmax} 2^{\circ} \mathrm{C}+\operatorname{Tmin} 2^{0} \mathrm{C}+50 \mathrm{ppm} \mathrm{CO}$ & 3340 & -15.10 \\
\hline & $\operatorname{Tmax} 2^{\circ} \mathrm{C}+\operatorname{Tmin} 2^{\circ} \mathrm{C}+100 \mathrm{ppm} \mathrm{CO}$ & 3438 & -12.60 \\
\hline & $\operatorname{Tmax} 2^{\circ} \mathrm{C}+\operatorname{Tmin} 2^{\circ} \mathrm{C}+200 \mathrm{ppm} \mathrm{CO} 2$ & 3631 & -07.70 \\
\hline & $\operatorname{Tmax} 4^{\circ} \mathrm{C}+\operatorname{Tmin} 4^{0} \mathrm{C}+50 \mathrm{ppm} \mathrm{CO}_{2}$ & 3036 & -22.80 \\
\hline & $\operatorname{Tmax} 4^{\circ} \mathrm{C}+\operatorname{Tmin} 4^{0} \mathrm{C}+100 \mathrm{ppm} \mathrm{CO}$ & 3144 & -20.10 \\
\hline & $\operatorname{Tmax} 4^{\circ} \mathrm{C}+\operatorname{Tmin} 4^{\circ} \mathrm{C}+200 \mathrm{ppm} \mathrm{CO}$ & 3327 & -15.40 \\
\hline \multirow{6}{*}{ Barisal } & $\operatorname{Tmax} 2^{0} \mathrm{C}+\operatorname{Tmin} 2^{\circ} \mathrm{C}+50 \mathrm{ppm} \mathrm{CO}$ & 4419 & -13.30 \\
\hline & $\operatorname{Tmax} 2^{\circ} \mathrm{C}+\operatorname{Tmin} 2^{\circ} \mathrm{C}+100 \mathrm{ppm} \mathrm{CO} 2$ & 4618 & -09.40 \\
\hline & $\operatorname{Tmax} 2^{\circ} \mathrm{C}+\operatorname{Tmin} 2^{\circ} \mathrm{C}+200 p p m \mathrm{CO}_{2}$ & 5016 & -01.60 \\
\hline & $\operatorname{Tmax} 4^{\circ} \mathrm{C}+\operatorname{Tmin} 4^{\circ} \mathrm{C}+50 \mathrm{ppm} \mathrm{CO} 2$ & 3442 & -32.50 \\
\hline & $\operatorname{Tmax} 4^{\circ} \mathrm{C}+\operatorname{Tmin} 4^{\circ} \mathrm{C}+100 \mathrm{ppm} \mathrm{CO}$ & 3607 & -29.20 \\
\hline & $\operatorname{Tmax} 4^{\circ} \mathrm{C}+\operatorname{Tmin} 4^{0} \mathrm{C}+200 \mathrm{ppm} \mathrm{CO}$ & 3924 & -23.00 \\
\hline \multirow{6}{*}{ Comilla } & $\operatorname{Tmax} 2^{\circ} \mathrm{C}+\operatorname{Tmin} 2^{\circ} \mathrm{C}+50 \mathrm{ppm} \mathrm{CO}_{2}$ & 4622 & -14.80 \\
\hline & $\operatorname{Tmax} 2^{\circ} \mathrm{C}+\operatorname{Tmin} 2^{\circ} \mathrm{C}+100 \mathrm{ppm} \mathrm{CO} 2$ & 4809 & -11.40 \\
\hline & $\operatorname{Tmax} 2^{\circ} \mathrm{C}+\operatorname{Tmin} 2^{\circ} \mathrm{C}+200 \mathrm{ppm} \mathrm{CO}$ & 5217 & -03.90 \\
\hline & $\operatorname{Tmax} 4^{\circ} \mathrm{C}+\operatorname{Tmin} 4^{0} \mathrm{C}+50 \mathrm{ppm} \mathrm{CO}$ & 3631 & -33.10 \\
\hline & $\operatorname{Tmax} 4^{\circ} \mathrm{C}+\operatorname{Tmin} 4^{0} \mathrm{C}+100 \mathrm{ppm} \mathrm{CO}$ & 3820 & -29.60 \\
\hline & $\operatorname{Tmax} 4^{\circ} \mathrm{C}+\operatorname{Tmin} 4^{0} \mathrm{C}+200 \mathrm{ppm} \mathrm{CO} 2$ & 4222 & -20.20 \\
\hline \multirow{6}{*}{ Sylhet } & $\operatorname{Tmax} 2^{0} \mathrm{C}+\operatorname{Tmin} 2^{0} \mathrm{C}+50 \mathrm{ppm} \mathrm{CO} 2$ & 5619 & +04.80 \\
\hline & $\operatorname{Tmax} 2^{\circ} \mathrm{C}+\operatorname{Tmin} 2^{\circ} \mathrm{C}+100 \mathrm{ppm} \mathrm{CO}$ & 5800 & +08.20 \\
\hline & $\operatorname{Tmax} 2^{\circ} \mathrm{C}+\operatorname{Tmin} 2^{\circ} \mathrm{C}+200 \mathrm{ppm} \mathrm{CO}$ & 6095 & +14.00 \\
\hline & $\operatorname{Tmax} 4^{0} \mathrm{C}+\operatorname{Tmin} 4^{0} \mathrm{C}+50 \mathrm{ppm} \mathrm{CO}$ & 4577 & -14.60 \\
\hline & $\operatorname{Tmax} 4^{\circ} \mathrm{C}+\operatorname{Tmin} 4^{0} \mathrm{C}+100 \mathrm{ppm} \mathrm{CO}$ & 4743 & -11.50 \\
\hline & $\operatorname{Tmax} 4^{0} \mathrm{C}+\operatorname{Tmin} 4^{0} \mathrm{C}+200 \mathrm{ppm} \mathrm{CO}$ & 5112 & -04.60 \\
\hline
\end{tabular}

Effects of Maximum, Minimum Temperature and Carbon dioxide $\left(\mathrm{CO}_{2}\right)$

The simulation study has also been conducted under different climatic scenarios of temperature and carbon dioxide concentration. Scenario likes, Tmax $2^{\circ} \mathrm{C}+\mathrm{Tmin} 2^{\circ} \mathrm{C}+200$ ppm $\mathrm{CO}_{2}$ had some positive effect on rice production but those positive effects were not so significant compared to other scenarios. The most significant negative effect was Tmax $4^{\circ} \mathrm{C}+$ Tmin $4^{\circ} \mathrm{C}+50 \mathrm{ppm} \mathrm{CO}_{2}$ (Comilla $33.1 \%$ rice yield reduced). Table 9 shows the various scenarios and their effects on rice production. From predicting rice yield under different 
scenarios, it is clear that temperature is one of the most dominant climatic factors, which may affect rice yield significantly in future.

The DSSAT model has been carried out in this study to see the possible effects of climate change on Boro rice yield in Bangladesh. The growth and yield of crops are directly related to the rate of photosynthesis and phenology and their response to temperature, solar radiation and rainfall. Optimum temperatures for maximum photosynthesis range from $25^{\circ} \mathrm{C}$ to $30^{\circ} \mathrm{C}$ for rice under the climatic conditions of Bangladesh. The simulations results suggest the maximum and minimum temperatures could significantly affect in rice yield, and the effect could become more pronounced if $4^{\circ} \mathrm{C}$ rises in temperature. Sensitivity analysis indicates that crop model is sensitive to $\mathrm{CO}_{2}$ levels and has a positive impact on rice yield. Although higher $\mathrm{CO}_{2}$ levels in future would balance the detrimental effects of increased temperatures to some extent but it would not be able to offset them. Currently, maximum area in Bangladesh is under HYV Boro rice cultivation. It is expected that in future the total rice area would be under HYV cultivation. However, even then the rice production is not projected to be adequate to meet the demand. Therefore, development of cultivars that would be able to withstand high temperature $\left(2^{\circ} \mathrm{C}\right.$ to $4^{0} \mathrm{C}$ temperature $)$ and water stress and have greater photosynthesis efficiency may mitigate the production problems projected for the next 50 to 100 years. Besides proper management practices (irrigation and fertilizer applications) would also help to meet the food demand under changing climatic condition in future. Public awareness of the impact of climate change on the agriculture production systems deserves priority consideration, and mitigating technologies must be developed, which will require increased public and private investment.

Table 10. Average percentage change of Boro rice yield under various climatic scenarios

\begin{tabular}{|c|c|}
\hline Climate change phenomena & $\%$ Change in rice yield \\
\hline \multicolumn{2}{|l|}{ a) Temperature effect } \\
\hline Increased Maximum Temperature $2^{\circ} \mathrm{C}$ & -6.09 \\
\hline Increased Maximum Temperature $4^{\circ} \mathrm{C}$ & -16.0 \\
\hline Increased Minimum Temperature $2^{\circ} \mathrm{C}$ & -4.17 \\
\hline Increased Minimum Temperature $4^{0} \mathrm{C}$ & -8.9 \\
\hline Increased $\mathrm{Tmax} 2^{\circ} \mathrm{C}+\mathrm{T} \min 2^{\circ} \mathrm{C}$ & -10.41 \\
\hline Increased $\mathrm{Tmax} 4^{\circ} \mathrm{C}+\mathrm{Tmin} 4^{\circ} \mathrm{C}$ & -22.87 \\
\hline \multicolumn{2}{|l|}{ b) Carbon dioxide effect } \\
\hline Increased $50 \mathrm{ppm} \mathrm{CO} 2$ & +3.47 \\
\hline Increased $100 \mathrm{ppm} \mathrm{CO} 2$ & +6.47 \\
\hline Increased $200 \mathrm{ppm} \mathrm{CO} 2$ & +11.97 \\
\hline \multicolumn{2}{|l|}{ c) Temperature and carbon dioxide Effect } \\
\hline Increased $\mathrm{Tmax} 2^{\circ} \mathrm{C}+\mathrm{Tmin} 2^{\circ} \mathrm{C}+50 \mathrm{ppm} \mathrm{CO} 2$ & -8.28 \\
\hline Increased $\mathrm{Tmax} 2^{\circ} \mathrm{C}+\mathrm{Tmin} 2^{\circ} \mathrm{C}+100 \mathrm{ppm} \mathrm{CO}$ & -4.95 \\
\hline Increased Tmax $2^{\circ} \mathrm{C}+\mathrm{Tmin} 2^{\circ} \mathrm{C}+200 \mathrm{ppm} \mathrm{CO}$ & +1.37 \\
\hline Increased Tmax $4^{\circ} \mathrm{C}+\mathrm{Tmin} 4^{0} \mathrm{C}+50 \mathrm{ppm} \mathrm{CO}$ & -24.66 \\
\hline Increased $\mathrm{Tmax} 4^{\circ} \mathrm{C}+\mathrm{Tmin} 4^{0} \mathrm{C}+100 \mathrm{ppm} \mathrm{CO}$ & -21.79 \\
\hline Increased $\mathrm{Tmax} 4^{\circ} \mathrm{C}+\mathrm{Tmin} 4^{0} \mathrm{C}+200 \mathrm{ppm} \mathrm{CO}$ & -14 \\
\hline
\end{tabular}


The impact of climate change on rice yields depend on actual patterns of climatic factors change in rice growing regions. Both higher maximum and minimum temperature reduce rice yields due to spikelete sterility and higher respiration losses. At the same time, rice production may be threatened in vulnerable regions. Overall, much uncertainty still exists about the true direction of the impacts of $\mathrm{CO}_{2}$ and temperature.

\section{ACKNOWLEDGMENTS}

The authors acknowledge Dr M Ashraf Ali and Dr Jobair Bin Alam, Professor Department of Civil Engineering, BUET. The Authors would like to thank Dr Md Abdur Rashid and Md Abdus Salam of Bangladesh Rice Research Institute (BRRI), Gazipur and A Z M Saleh for their kind support throughout the study.

\section{REFERENCES}

Ahmed, A and S Ryosuke. 2000. Climate change and agricultural food production of Bangladesh: an impact assessment using GIS-based biophysical crop simulation model. Center for Spatial Information Science, University of Tokyo, 4-6-1 Komaba, Japan.

Bangladesh Economics Review. 2011. Government of the People's Republic of Bangladesh. Ministry of Finance, Dhaka.

BARC, 2005. Fertilizer Recommendation Guide-2005, Bangladesh Agricultural Research Council (BARC), Dhaka, Bangladesh. Soils publication no. 45, ISBN: 984-32-3166-X.

Basak, J K, M A Ali, M N Islam and M A Rashid. 2010. Assessment of the Effect of Climate Change on Boro Rice Production in Bangladesh using DSSAT Model; Journal of Civil Engineering (IEB), 38 (2) (2010) 95-108.

Basak, J K. 2009. Climate Change Impacts on Rice Production of Bangladesh: Results from a Model. Published by Unnayan Onneshan (www.unnayan.org), Dhaka, Bangladesh.

BRRI, 2006. Improvement of standard Boro rice. BRRI (Bangladesh Rice Research Institute) Annual Report for July 2005-June 2006. Plant Breeding Division, BRRI, Gazipur, Bangladesh.

Hoogenboom, G, J W Jones, C H Porter, P W Wilkens, K J Boote, W D Batchelor, L A Hunt and G Y Tsuji (Editors). 2003. Decision Support System for Agrotechnology Transfer Version 4.0., Volume 1: Overview. University of Hawaii, Honolulu, HI.

IPCC, 2007. Summary for Policymakers. In: Climate Change 2007: The Physical Science Basis. Contribution of Working Group I to the Fourth Assessment Report of the Intergovernmental Panel on Climate Change [Solomon, SD, Qin, M, Manning, Z, Chen, M, Marquis, KB, Averyt, M, Tignor and HL Miller (eds.)]. Cambridge University Press, Cambridge, United Kingdom and New York, NY, USA.

Karim, Z, S G Hussain and M Ahmed. 1996. Assessing Impact of Climate Variations on Foodgrain Production in Bangladesh, Water Air and Soil Pollution, 92, 53-62.

Mahmood, R. 1998. Air temperature variations and rice productivity in Bangladesh: A comparative study of the performance of the YIELD and CERES-Rice models. Ecological Modeling, 106, 201-212.

Mahmood, R, M Meo, D R Legates, and M L Morrissey. 2003. The Professional Geographer, 55(2), 259-273.

Ritchie, J T, E C Alocilja, U Singh, and G Uehara. 1987. IBSNAT and the CERES-Rice model. Weather and Rice, Proceedings of the International Workshop on the Impact of Weather Parameter on Growth and Yield of Rice, 7-10 April, 1986. International Rice Research Institute, Manila, Philippines, pp. 271-281. 